\title{
Flooding trends and their impacts on coastal communities of Western Cape Province, South Africa
}

\author{
Kaitano Dube (iD) Godwell Nhamo • David Chikodzi
}

Accepted: 15 June 2021 / Published online: 25 June 2021

(C) The Author(s), under exclusive licence to Springer Nature B.V. 2021

\begin{abstract}
Climate change-induced extreme weather events have been at their worst increase in the past decade (2010-2020) across Africa and globally. This has proved disruptive to global socio-economic activities. One of the challenges that has been faced in this regard is the increased coastal flooding of cities. This study examined the trends and impacts of coastal flooding in the Western Cape province of South Africa. Making use of archival climate data and primary data from key informants and field observations, it emerged that there is a statistically significant increase in the frequency of flooding and consequent human and economic losses from such in the coastal cities of the province. Flooding in urban areas of the Western Cape is a factor of human and natural factors ranging from extreme rainfall, usually caused by persistent cut off-lows, midlatitude cyclones, cold fronts and intense storms. Such floods become compounded by poor drainage caused by vegetative overgrowth on waterways and land pollution that can be traced to poor drainage maintenance. Clogging of waterways and drainage systems enhances the risk of
\end{abstract}

K. Dube $(\bowtie)$

Department of Ecotourism Management, Vaal University of Technology, Private Bag X021, Vanderbijlpark 1911, South Africa

e-mail: kaitanod@vut.ac.za

G. Nhamo - D. Chikodzi

Institute of Corporate Citizenship, University of South

Africa, PO Box 392 Pretoria 002, Pretoria, South Africa flooding. Increased urbanisation, overpopulation in some areas and non-adherence to environmental laws results in both the affluent and poor settling on vulnerable ecosystems. These include coastal areas, estuaries, and waterways, and this worsens the risk of flooding. The study recommends a comprehensive approach to deal with factors that increase the risk of flooding as informed by the provisions of both the Sustainable Development Goals framework and the Sendai Framework for Disaster Risk Reduction 2015-2030 in a bid to de-risking human settlement in South Africa.

Keywords Coastal flooding $\cdot$ Natural hazards $\cdot$ Cape Town - Western Cape $\cdot$ Climate change

\section{Introduction}

The world over, many people are resident in coastal areas. The romantic connection between humanity and coastal communities has a long history dating back to the pre-civilisation era. According to Hallegatte et al. (2013), coastal cities are witnessing an increase in the frequency, intensity and impact of coastal flooding. The cost of flooding can be attributed to several factors such as rapid urbanisation, the increased construction and installation of other assets along the coastal line and climate change (Amoako \& Frimpong Boamah, 
2015; Dhiman et al., 2019). Chan (2018) argue that hydrological hazards faced by coastal cities emanate from a combination of factors such as uncontrolled urban development, climate change, and sea level rise.

Climate change has ushered in a new era of challenges for coastal towns and cities. These areas experience nature's backlash in the form of intense rainfall, sea level rise, in some instances, tropical cyclones and increasing tidal activity and storm surges (Dube et al., 2020a, 2020b). The increasing incidence of extreme weather events is worrying as it presents complex challenges for coastal communities' socioeconomic development. According to Ogie et al. (2018), critical coastal infrastructure such as pumps, flood gates, and embankments are particularly vulnerable to increased floods. In addition, transport networks remain vulnerable to coastal flooding (Duy et al., 2019). This is likely to threaten the achievement of the global inclusive Sustainable Development Goals (SDGs) that are set to be achieved in 2030 (United Nations, 2015).

There is, therefore, a growing consensus and worry that coastal areas are increasingly becoming global hotspots for climate change-induced extreme weather disasters (Chan et al., 2018). Balica et al. (2012) indicate the need to enhance understanding of global vulnerability by explicitly focusing on coastal flooding, which is becoming more common and problematic across the world. Regardless of coastal flooding's recognition as a significant challenge to most areas, the knowledge of the actual extent of climate change risk to coastal areas remains a challenge to most areas in Africa (Kithiia, 2011). As a consequence, addressing flood resilience in that context is problematic. According to Handayani et al. (2019), resiliencebuilding must be a key focus in ensuring coastal areas' sustainability in the wake of climate change. In light of this call, this study examines and documents the trends and impacts of flooding in the coastal province of Western Cape, South Africa. Although the principal aim of the study is to examine trends and impact of floods in the Western Cape province in general, the main focus will be on urban areas where the greatest socio-econimic impacts occur. Two critical research questions are raised: (1) What has been the long-term flood occurrence in the Western Cape province? (2) What has been the socio-economic impact of these floods on the Western Cape province?

\section{Literature survey}

Extreme weather events remain among the global challenges that both inland and coastal communities must contend with in the quest to ensure sustainable development. Apart from the COVID-19 pandemic, which has had a devastating impact on global economies in 2020 (Nhamo et al., 2020), climate change is a wicked problem that the world must battle with going forward if development target aspirations are to be met. The challenge of extreme weather events is particularly pronounced and felt by most developing countries, which still lack the means for adaptation or maladapt (Leal Filho, 2018, 2019; Mirza, 2003). In most cases, there is a clear link between communities' income levels and adaptive capacity. By nature, adaptation requires that nations and states invest more resources into climate change resilience initiatives. Experience has often shown that such resources are often not available for most developing countries, even for basic needs. Therefore, it is anticipated that climate change will likely worsen marginalised communities' poverty levels due to the impacts pf extreme weather events and costs associated with the damage.

One of the impacts of extreme weather events that has caused challenges for development agencies and planners is the issue of flooding in coastal urban spaces. Besides flooding (a process of submerging of land that is usual dry by overflowing water), coastal communities must battle with other climate change induced challenges such as sea level rise, coastal erosion, ocean pollution, rising sea surface temperature, coral bleaching and severe droughts (IPCC, 2019). These coastal challenges have disturbed coastal communities' lives and livelihoods with far-reaching implications for inland communities, which often depends on coastal areas for recreation, food, and other critical supplies. This presents severe challenges for coastal urban communities in Sub-Saharan Africa, where coastal areas are also battling the challenges caused by rapid urbanisation (Cian et al., 2019; Dodman et al., 2017).

Cities and communities in Southern and Eastern Africa have not been spared from climate changerelated hazards, with many cities battling flooding. A study by Braccio (2014) reveals that in Maputo, a coastal city in Mozambique, there have been increasing incidences of flooding due to the compounded impact of rising sea levels and intense rainfall activity 
attributed to climate change. As Kabanda (2020) finds, Mombasa's vulnerability in Kenya due to rising sea level has placed infrastructure such as roads and buildings under flood threat. On the other hand, the threat of flooding in South Africa's coastal areas is not well documented, with very few studies focussing on the issue (see, for example, Fitchett et al., 2016; Dalu et al., 2018). This is also the picture across many other places in Southern Africa. Consequently, there are fears that this will curtail the adoption of adequate adaptation and resilience measures.

Despite fears by communities and preliminary evidence of the catastrophic impact of floods in coastal areas there has been little effort to adequately address this challenge. According to Fitchett et al. (2016), the challenge of coastal flooding is a real perceived threat by tourism businesses operating in the coastal towns of the Eastern Cape province of South Africa. In another study, Dalu et al. (2018) found that informal settlements that were located on high slopes, degraded slopes and those close to drainage channels were likely to experience significant damages from flooding. This raises concerns as to the impact of such shocks on vulnerable groups and their capacity to recover and adapt from such threats.

Cape Town, which is located in the Western Cape, has not been immune to flooding. Taylor and Davies (2019) note that the city of Cape Town, the 10th most populous city in Africa often suffers from the impacts of flooding with a devastating impact on railway lines, parking lanes, roads, and power supply and communication infrastructure. Fears are also rife that these impacts will worsen due to climate change induced sea level rise in the city and other areas surrounding it (Dube et al., 2021). Due to increased urbanisation, stormwater is also presenting unique challenges for the City of Cape Town (Taylor, 2019). Climate change studies have established that there are also fears that with the increased frequency and incidence of the El Niño-Southern Oscillation in the Southern Hemisphere, there is an anticipation that this will likely see an increased frequency in coastal flooding. Rasmusson and Wallace (1983), established that the El NiñoSouthern Oscillation is closely linked to sea levels' variability, which can worsen sea level rise and lead to increased coastal flooding.

Western Cape is one of the most urbanised communities and one of the most unequal societies in South Africa (Gwaze et al., 2018). As such the threat of flooding affects different communities differently, with the marginalised communities bearing the brunt of such events. The recent drought in Cape Town exposed the vulnerabilities along these economic and social lines (Enqvist \& Ziervogel, 2019). Given past experiences, droughts require attention as they often result in mass displacements, which undermines peoples' livelihood security and infrastructural damage (Dube \& Nhamo, 2020a, 2020b). The devastating impacts of floods were also witnessed in 2019 in Mozambique and other Southern African Development Community (SADC) countries in the wake of Tropical Cyclones Idai and Kenneth (Phiri et al., 2020). There is therefore a need for a thorough understanding of flood occurrences and associated risks. Such an undertsnading is more critical now than ever before to allow communities to build resilience and adopt risk reduction measures. In as much as single cases of flood events are documented, there is no study in the SADC area that looks at the long-term trends of floods. Hence, this study examines and documents the trends and impact of floods that have occurred in the Western Cape over the last 120 years. The study seeks to understand flood frequency and its impact on the community, development, and society at large.

\section{Research design}

The Western Cape Province is an area located on the southernmost part of South Africa and the African continent (Fig. 1). It is the same place that is home to the populous city of Cape Town and the iconic Table Mountain (Dube et al., 2020a, 2020b). The province lies between coastlines from two oceans namely: the Indian Ocean on the east and the Atlantic Ocean on the west coast. The two oceans separate at the Cape Agulhas. The province has a predominantly Mediterranean climate that is typified by warm and mostly dry summers and cold wet winters. The two oceans play a critical role in shaping the climatic and weather patterns of the area. The Western Cape Province has been in the news for the devastating impacts of extreme weather events, particularly the recent drought of 2017/18 that threatened the water supply system of one of South Africa's most populous cities and tourism destinations (Dube et al., 2020a, 2020b). The City of Cape Town and other 


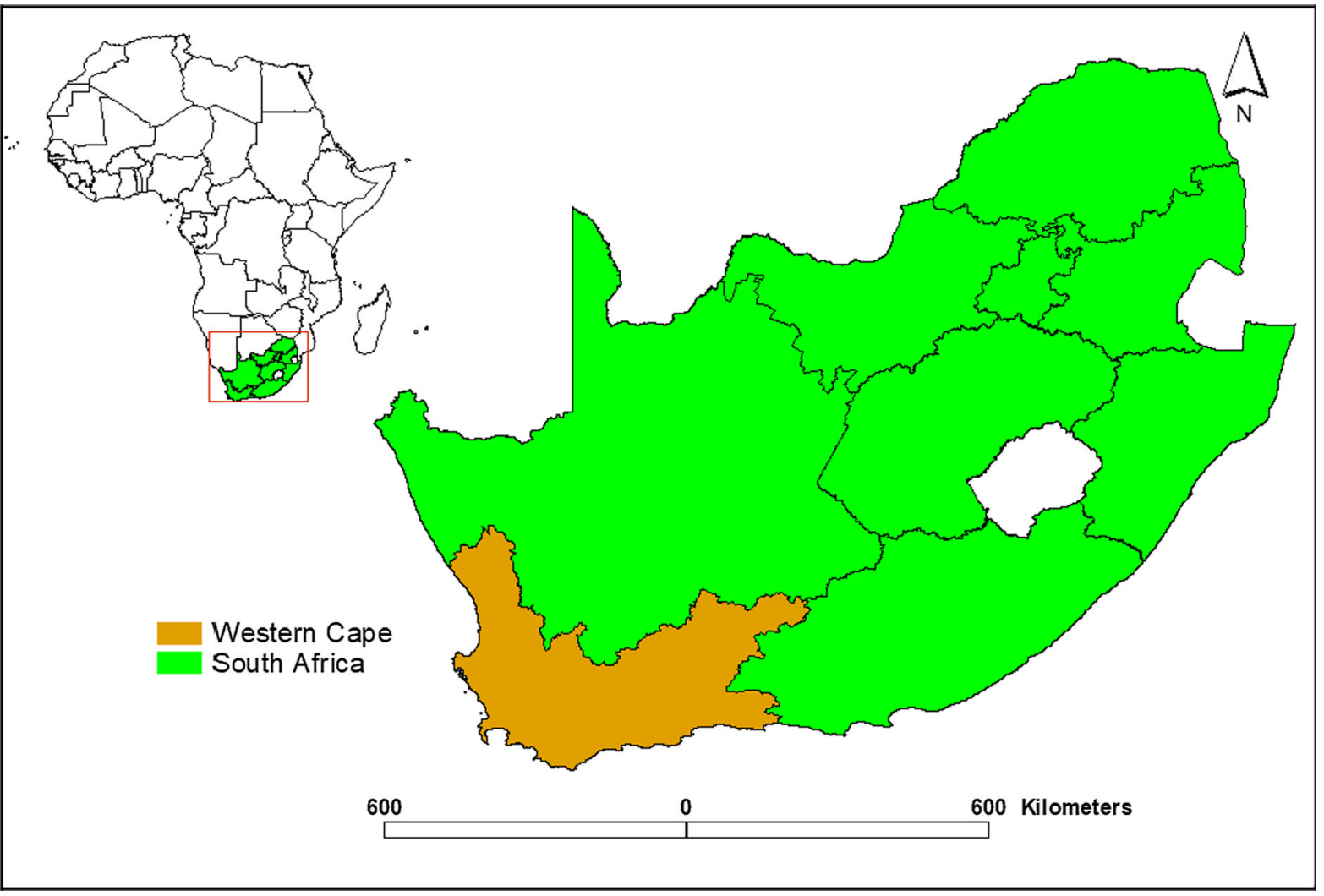

Fig. 1 Location of Western Cape Province in relation to South Africa and Africa Source: Authors

places in the Western Cape Province are well known for their vulnerability to extreme weather events, with the City of Cape Town often dubbed the "Cape of Storms" by many of its citizens. Rouault, (2002) notes that the Agulhas Current, whose location is the east coast of South Africa, with a bearing on and off the Eastern and Western Cape coast, is partly responsible for severe weather events in the province.

In Western Cape latent heat fluxes often causes low-level advection of moisture, which in turn causes the intensification of storms and tornadoes, causing flooding. Stramma and Lutjeharms (1997) noted that the Agulhas Current is one of the most intense western current boundaries in the Southern Hemisphere, and White (2000) observed two such severe storms during 1998/99 summer on the Agulhas Current. According to Mukheibir and Ziervogel (2007), the March 2003 and April 2005 intense storms and flooding were reported in Cape Town and the Western Cape province.
A case study research approach was adopted for this study. The study utilised data obtained from the South African Weather Services' (SAWS) archives for the period 1900 to 2018. Additional data were obtained from field observations and key informant interviews from various Western Cape admimisttrative districts that took place between February and December 2020. A snow ball sampling technique was followed in the selection of 15 key informants, which formed part of the study. Key informants comprised of staff from the City of Cape Town that included planners, environmental engineers, museum curators, protected area personnel, tradtional community leaders and climate experts from the province. Such key informant interviews took between 45 and $60 \mathrm{~min}$. Questions for key infrmants centered on documenting the climate history of the area, experiences with the floods, possible causes and possible solutions to flooding among other key questions pertinent to the study. The use of key informants interviews is an acceptable standard, methodological approach, which has been used 
in previous similar studies by Lo et al. (2017) and Twongyirwe et al. (2018). The approach can yield valid results and allows researchers to collect high quality data within a short period of time from fewer people in a cost effective manner. This methodological approach also addreses the constraints posed by the COVID-19 pandemic of ensuring phsycical and social distancing as it minimised contact with a lot of people. SAWS is one of the most resourced meteorological organisations in terms of weather stations that boasts a wide array of weather and climate equipment networks (Fig. 2).

Data analysis was conducted using XLSTAT 2020.5.1 that was run on a Microsoft Excel sheet. A time series was analysed using the Mann-Kendall trend test to determine the presence of trends. The Confidence interval was set at $95 \%$, and the Significance level was set at 5\%. The Mann- Kendall trend test was also used to plot the Sen's Slope. The Mann-
Kendall trend test is a commonly used parametric tool used in climate and hydrological studies that enjoys wide usage and has been used in similar studies by other scholars (Hamed, 2008; Hu et al., 2020). Choropleth maps showing flood hotspots in the study area were produced in a Geographic Information System using flood incident count at local municipality level as a measure. Frequently flooded areas were denoted by increasing the colour intensity on the map. Primary and secondary qualitative data was analysed using content and thematic analysis.

\section{Results and discussion}

The study found that between 1900 and 2018, at least 334 major flood events occurred in the Western Cape, with a mean annual number of floods being 2.9. The highest number of annual flood events over the period
Fig. 2 Some Key assets utilised by South African Weather Services Source: Authors

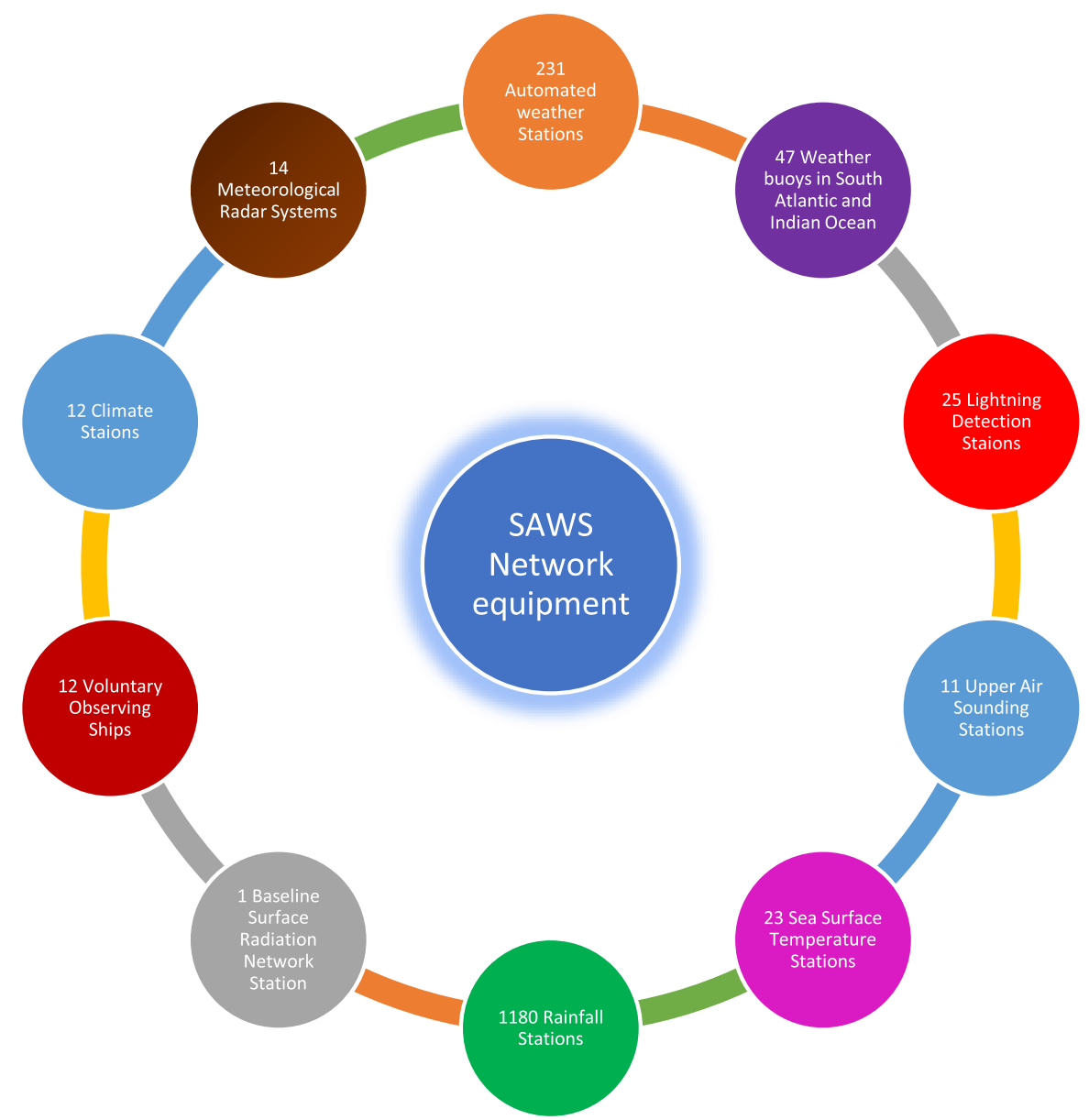


of study is 20, which occurred in 2008. The secondhighest number of flood events were recorded in 1981, where 15 floods were recorded. The third-highest flood years were recorded in 2004, 2005 and 2006, where 13 floods were recorded in each year. Consequently, the frequency of floods has been higher during the past four decades as compared to earlier periods (Fig. 3). In the first half-century, the average number of floods was at less than two flood events per year in the province, with the last century having peaked up to slightly more than four flood events per year. Figure 3 shows that there is a statistically significant ( $p=0.0001, \alpha=0.5$ ) increase in the number of flooding events occurring in Western Cape province over the period of study.

The observed increase in coastal flooding in the Western Cape Province in Fig. 3 confirms earlier findings in other parts of the world where coastal flooding is on the increase due to extreme weather events induced by climate change and other urban challenges as reported by Hirabayashi, (2013) and also Kim, (2017). One of the critical drivers of coastal flooding in Western Cape Province is high sea tides and intense rainfall activity. A study by Dube et al. (2021) found that some of the recent floodings observed in the City of Cape Town, for example, were worsened by sea level rise confirming earlier findings by Park and Lee (2020). Flooding in the Western Cape Province is worrying as it has far reaching socio-economic impacts on one of the most urbanised provinces and areas in the entire Southern Africa.

The study found that flooding was mainly concentrated in the areas close to the coast, with the highest flood prevalence concentrated around the City of Cape Town and areas that are to the east of the province (Fig. 4). Areas to the South East of the Cape Winelands district and areas to the South of the Cape Winelands seems to be most affected by the number of floods, whereas central Eden also experiences the highest number of floods. In the Cape Winelands District, the areas between Montagu and Ashton town are also considerably affected by flooding. The area which lies along the R62 road is prone to flooding due to several factors. The interviews were conducted with key informants where it was revealed that the area is susceptible to flooding due to its mountainous terrain with water being channelled towards a mountain gorge which the R62 road runs through. Other flood hotspots include areas near South East coastal areas of Overberg District east of Cape Agulhas near Strus Bay. In the Garden route area, areas around Plettenberg Bay

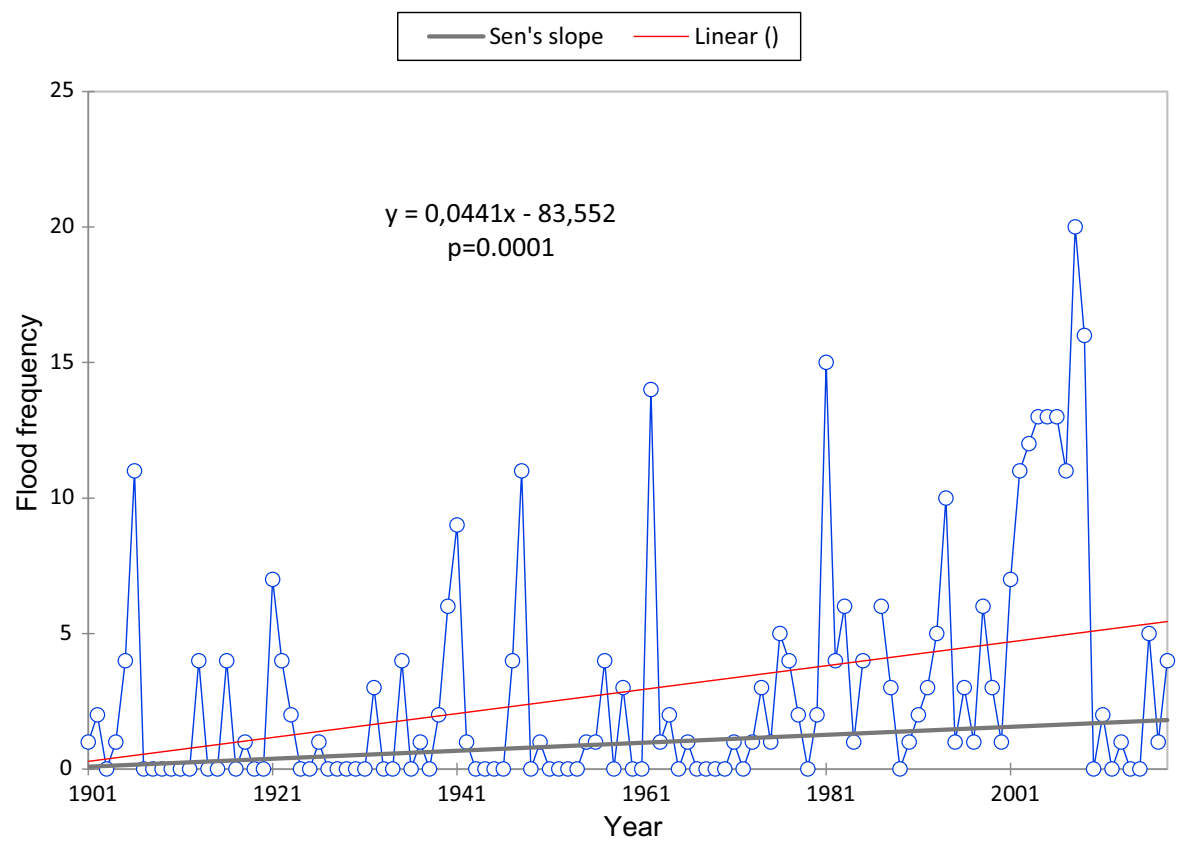

Fig. 3 Flooding frequency and trends in Western Cape province 1900-2018 Source: Authors, Data from SAWS (2020) 


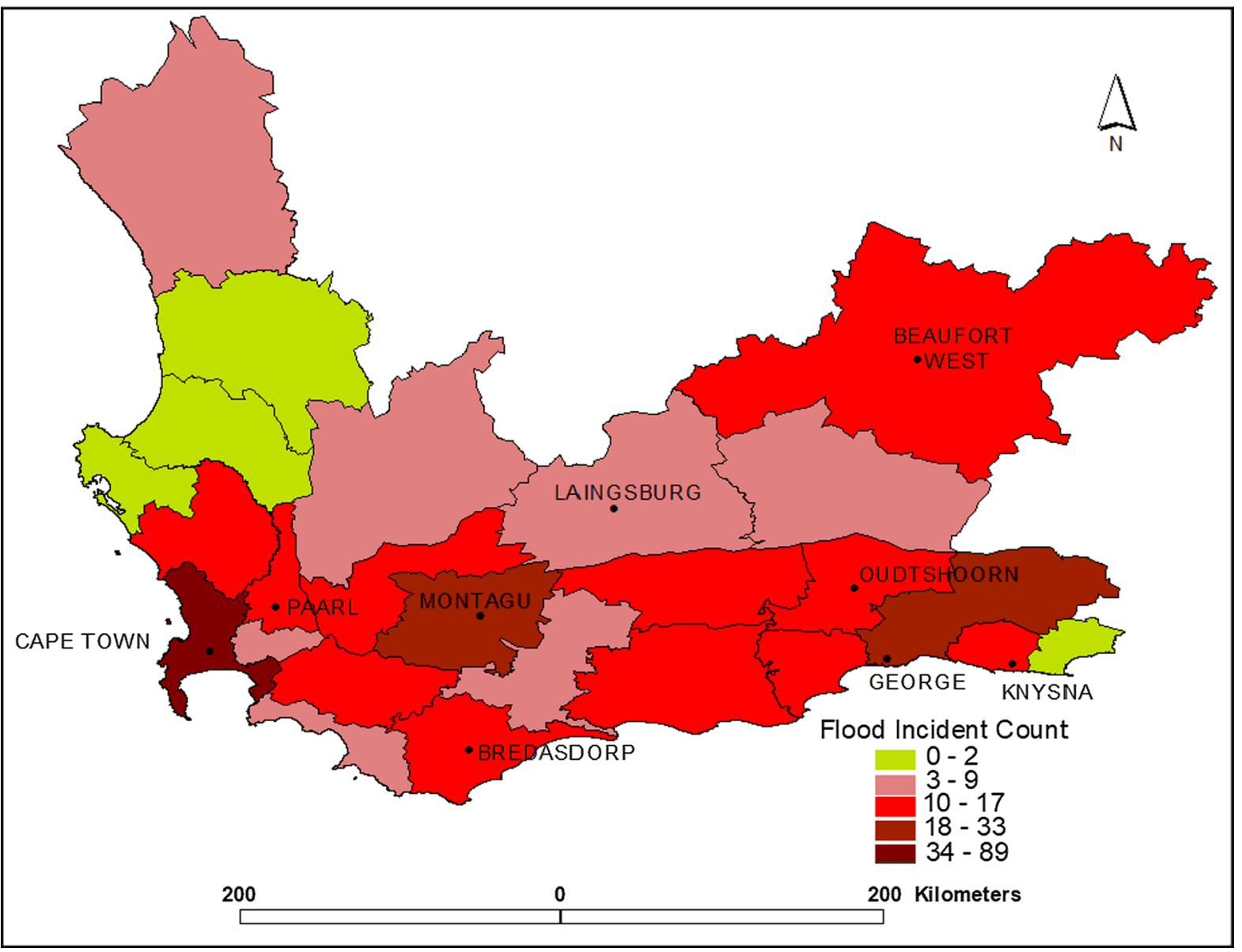

Fig. 4 Flood count and risk analysis map of Western Cape province between 1900 and 2018 Source: Authors, Data from SAWS (2020)

were identified as flooding hotspots. From Fig. 4 it emerges that floods tend to be concentrated along the coastline. However, by and large, the West Coast and Central Karoo areas are not as affected due to semiarid and desert conditions that prevail, with flush floods occurring once in a while.

Information gathered from the key informants revealed that heavy rainfall along the Kogmanskloof Mountain Pass along the R62 road often results in flooding in areas around the pass. Based on evidence from the Western Cape Provincial Government report and key informants in the area, one of the most memorable floods in the area is the Montagu flood of March 2003 which went on to be declared a national disaster. The record flood occurred as a consequence of a cut-off low that resulted in the Montagu area receiving $178 \mathrm{~mm}$ of rainfall in 1 day on the 23rd of March 2003. The total monthly rainfall for that month went up to $241 \mathrm{~mm}$, which became one of the wettest days in the history of the area. That particular flood event damaged roads, factories in Ashton town, farms, schools and had a huge impact on tourism. The De Hoop Nature Reserve's main road was washed away, and Goukamma Nature Reserve access road was also badly damaged in a development that costed Cape Nature more than R1 million. The traditional leadership in the area fears that the flood event and other subsequent floods washed away several archaeological artefacts from the Khoisan San community in mountains in the area leading to a loss of important historical heritage. The flood also had an adverse impact on the Klein Karoo Arts Festival as the area was declared a disaster zone because of that flood event. The access road between Ashton and Montagu was disrupted just in time for the festival cutting off tourist access. 
Field observations and information from key informants revealed that given a significantly large basin and water channelled from mountain zones, flood risk is also high in that area. Another factor that promotes occasional floods is that the area seems to be experiencing successive years of flooding and drought, given its geographic location, which is transitional to the central Karoo, which is semi-desert. Pollution from urban and farming activities in the catchment further promotes the heavy growth of weeds within the Kogmanskloofrivier river. This reduces the rate of water outflow from the area and ultimately increases the risk of flooding in the area.

It emerged during fieldwork that the government is working on upgrading road infrastructure in the area so as to mitigate the increased impact of flooding on human settlements and infrastructure. The infrastructure includes elevating the road and making bigger elevated bridges to allow for more water to flow at any given time without causing flooding. The bridge in Ashton town, for example, was being upgraded to allow more water flow. It remains to be seen how such upgrades will limit the disruptions caused by floods to Montagu and Ashton town's two communities.

\section{Socio-economic impact of floods in Western Cape}

It emerged from the SAWS records, damages induced by flooding in the Western Cape ranged from infrastructure (roads, bridges, and rail lines), loss of properties, homes, damages to vineyards, damages to informal settlements, and injury and loss of human lives. In as much as the increased socio-economic and human cost can be tracked back to increased frequency of flooding events, increased urbanisation and affluence has over the years worsened this phenomenon.

Table 1 shows some of the most significant and high impact floods that have been witnessed in the Western Cape between 1901 and 2018. The flooding incidences recorded in various places in the Western Cape show that the flooding events in the province have led to the death of more than 129 people across province. There were very few deaths witnessed before 1980, with only three fatalities attributed to floods. The single highest number of fatalities were recorded in 1981 when a staggering 104 people were killed in a single incident by a raging flood that wiped away almost the entire small town of Laingsburg. On 25 January 1981, a cloud outburst caused one of the greatest floods in the Great Karoo. Given the geohydrological makeup of the area, where the soil cannot absorb much water, the cloud outburst resulted in a $6 \mathrm{~m}$ high flood after the Baviaans and Buffels rivers. The two rivers have their confluence in the town, and they bursted their banks, destroying 185 houses and 23 businesses.

That flooding incident went on to be labelled as one of the worst natural disasters in South Africa. In addition to the destruction of properties and businesses, the flood led to the washing away of animals and the town's tourism infrastructure. During this 1 in 100 year flood incident, the Great Trek Monument, which is an important Dutch historical monument, which was constructed in 1938, was washed away. While the greater part of the monument was recovered after the flood, the monument's pedestal was lost and was only found after another flood in June 2015. The impacts of floods are well documented, which have played both a positive and negative role in heritage properties (Liu, 2019; Reimann, 2018). While floods destroyed the monument, they also created another historical monument. Post the flood a Flood Museum was constructed in the same town.

It would appear from key informants' accounts that the 1981 Laingsburg natural disaster was partial caused settlements that were established without proper risk analysis and consideration. Settlements, which are established without a proper risk assessment in the form of environmental impact assessment remain a worry across the country. This is particularly so, given the additional vulnerabilities induced by climate change-induced weather extreme events. Climate change-induced extreme weather events have the potential to amplify natural events, including rainfall patterns and intensity. Field observation revealed that even after the disaster, a look at the area shows that human development, including commercial infrastructures such as hotels, lodges, restaurants, and a hospital, is still located in flood zone. The adjustment to address the risk is crucial to current and future urban sustainability as part of disaster risk reduction. In that vein, the 2030 Agenda for Sustainable Development, particularly the Sustainable Development Goal Target 11.5 , seeks to reduce the number of fatalities and economic losses relative to the gross domestic product caused by disasters, focusing on the poor (United Nations, 2015). Similar aspirations are encompassed in the Sendai Framework for Disaster Risk Reduction 
Table 1 Most significant flood events in Western Cape

\begin{tabular}{|c|c|c|}
\hline Year & Area & Impact 1905 \\
\hline 1905 September & George & 15 houses destroyed \\
\hline 1905 September & Oudtshoorn & 41 houses destroyed \\
\hline 1906 December & Swellendam & 120 houses destroyed \\
\hline 1906 December & Touws River & 3 people died \\
\hline 1916 May & Knysna & Bridge washed away \\
\hline 1941 April & Beaufort West & $\begin{array}{l}55 \text { families left homeless } \\
\text { One person drowned }\end{array}$ \\
\hline 1956 December & Tulbach & Vineyard and Orchard Damage \\
\hline 1957 August & Cape Town & Many people injured \\
\hline 1976 July & Paarl & Dubbed worst flood in 25 years \\
\hline 1976 July & Wellington & Dubbed worst flood in 25 years \\
\hline 1981 January & Laingsburg & $\begin{array}{l}\text { Dubbed one of the worst natural disasters in South Africa } \\
104 \text { people drowned } \\
185 \text { houses and } 23 \text { businesses destroyed } \\
\text { Only } 21 \text { homes escaped damage }\end{array}$ \\
\hline 1983 June & Cape Town & Millions of Rand property destroyed \\
\hline 1983 September & Cape Town & Millions of Rand property destroyed \\
\hline 1983 June & Malmesbury & Millions of rand worth of damage \\
\hline 1983 June & Montagu & Millions of rand worth of damage \\
\hline 1993 April & Cape Town & Dubbed worst storms in 30 years \\
\hline 1993 July & Hermanus & Highest Flood in Breede River in 50 years \\
\hline 1994 June & Cape Town & 400 people left homeless \\
\hline 1999 April & Cape Town & Flooding accompanied by a mudslide \\
\hline 2001 July & Cape Town & 3500 people left homeless \\
\hline 2002 May & Bakoven & Millions of rand damages \\
\hline 2002 May & Betty’s Bay & Millions of rand damage \\
\hline 2002 May & Bolberrgstrand & Millions of rand damage \\
\hline 2002 July & Cape Town & 1000 people displaced \\
\hline 2002 May & Hermanus & Millions of rand damage \\
\hline 2003 March & Ashton & 12-million-rand damage \\
\hline 2003 August & Cape Town & Thousands left homeless \\
\hline 2004 August & Bonniavale & 2 dead \\
\hline 2004 October & Cape Town & 200 homes damaged \\
\hline 2004 December & George & Extensive damage to property \\
\hline 2005 April & Bredasdorp & People left homeless \\
\hline 2005 June & Cape Town & 100 shacks affected \\
\hline 2005 January & George & 4 hikers died in Kaaimans' River \\
\hline 2005 June & Khayelitsha & 20 shacks affected \\
\hline 2005 April & Overstrand & People left homeless \\
\hline 2005 April & Thewaterskloof & People left homeless \\
\hline 2008 June & Cape Flats & 5500 left homeless \\
\hline 2008 July & Cape Flats & 16000 people affected \\
\hline 2008 November & Cape Winelands & R1 billion worth of damages \\
\hline 2008 February & Herold Union District & 3 drowned \\
\hline 2005 May & Cape Town & 500 houses destroyed \\
\hline
\end{tabular}


Table 1 continued

\begin{tabular}{lll}
\hline Year & Area & Impact 1905 \\
\hline & & 1700 people affected \\
& & 28 informal settlement affected \\
2013 January & Cape Town & 4 killed \\
2018 June & Cape Metropole & 500 structures affected \\
2018 February & Montagu & 4 people killed \\
2018 February & Caledon & 5 people died \\
\hline
\end{tabular}

Data from South African Weather Services (2019)

2015-2030 (United Nations Office for Disaster Risk Reduction, 2015).

The Western Cape Province case study reveals that flood risks in urban areas are on the increase. Such risks primarily affect the poor. Extreme weather events such as floods often destroys homes and livelihoods. Evidence from the study reveals that flooding has in the past destroyed several shacks and homes. The worst affected areas in the past have been areas around George, Cape Town, Hermanus, Cape Flats and Khayelitsha. Apart from the Western Cape Province, similar observations have been made elsewhere in African states and other developing states that are located in coastal areas. Some of the affected areas includes Manila, Philippines (Zoleta-Nantes, 2002), Nigeria, (Adelekan, 2010; Echendu, 2020) and China (Jiang et al., 2018).

According to Douglas (2008) and Douglas (2017), the unjust water and climate are flooding the poor along with the coastal towns in Africa. The situation can be attributed to increasing urban poverty and rapid urbanisation and urban sprawl that has left many condemned to a life of squalor. Most urban councils in the coastal Western Cape and, in many respects, other urban areas in South Africa are failing to meet the demands of an ever-increasing housing backlog. Consequently, most urban migrants are settled in informal settlements where the settlements are unplanned and often in disaster-prone areas such as waterways and, in some instances, fragile ecosystems prone to flooding and other disasters. In Cape Town, for example, field observations revealed that the mushrooming of informal settlements magnified by the ongoing land grabs in the Cape Flats resulted in many building houses on waterways and fragile ocean sand dunes in densely populated areas, which exposed thousands to flood and fire disasters (Fig. 5). Therefore, it is not surprising that the City of Cape Town has witnessed increased incidences and cost of residents' displacement and property loss due to the combined effect of extreme weather events, urban sprawl and invasion of disaster areas by city dwellers.

The debate of flooding and climate change becomes central, as flooding disasters are driving many people around the globe into poverty. This sentiment is shared by Jordhus-Lier et al. (2019), who noted that the City of Cape Town flooding is a growing concern that requires focus and attention by developing climate change adaptation. In doing so, there is a need to address factors that induce vulnerabilities. According to Ribot (2014), addressing vulnerabilities requires an approach that considers the root causes of the crises so that transformative solutions can be found, often lacking in climate change adaptation studies. In this regard, addressing vulnerabilities must consider various matrices at play. These include climatic factors and factors that push people into settling in ecosensitive areas and waterways and considering aspects that deal with rapid rural to urban migration. Finally, dealing with aspects of refuse waste and drainage clogging in many urban setups in the Western Cape and across the country. In recent years, urban inequality has featured storngly in the mix, with politics playing a central role in urban settlement issues, resulting in wanton settlement development and land grabs, in some instances in areas that are not suitable for settlement. 


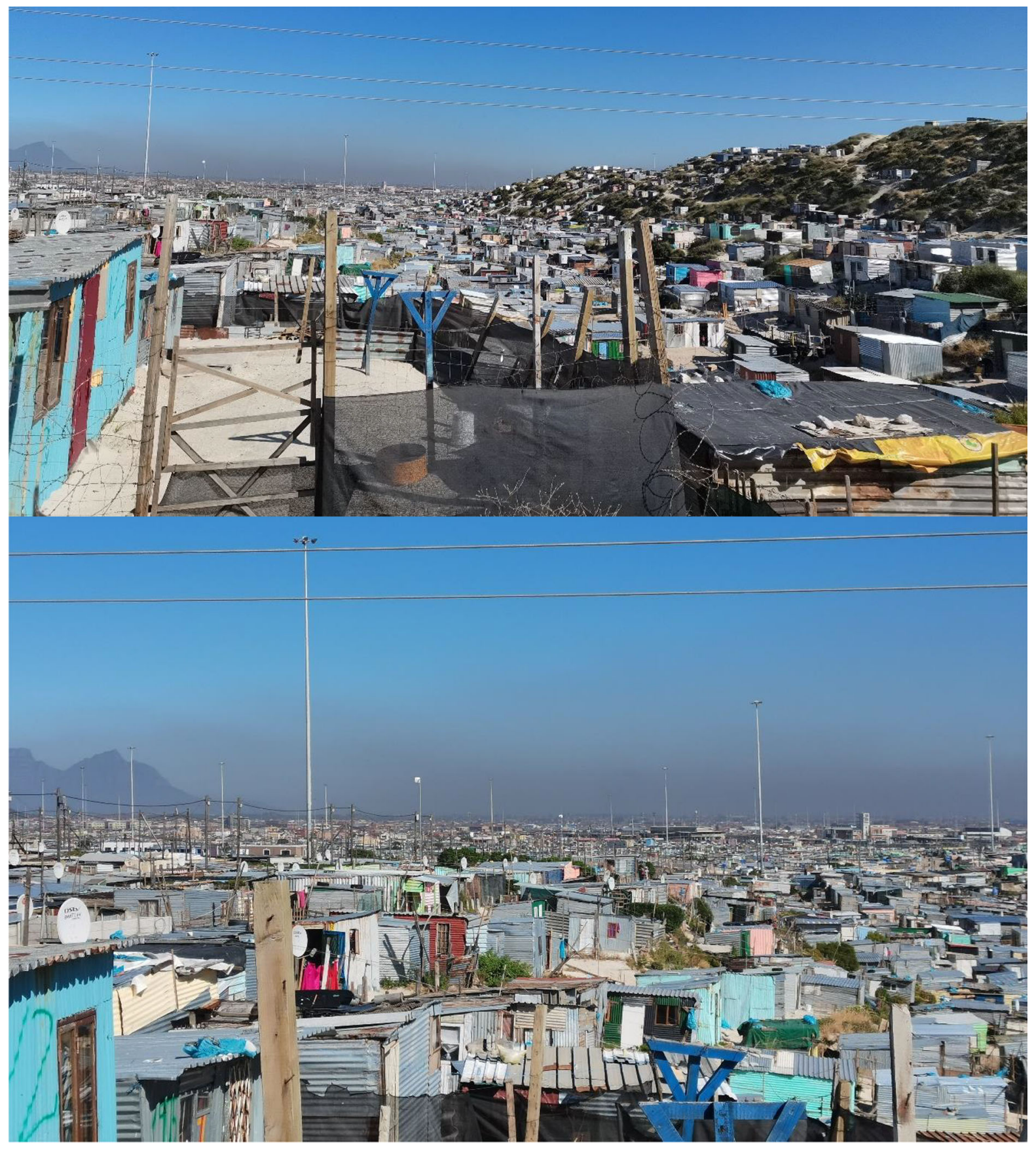

Fig. 5 Informal settlement built on unstable dunes and waterway in Khayelitsha, Cape Town Source: Authors, Fieldwork 2020

A recent study by Dube et al. (2020a, 2020b) noted that flooding in Cape Town was not only a factor of poverty as the affluent were also being hit hard by the compounded effect of sea-level rise and intense storm activity in the coastal city. Addressing vulnerabilities is, therefore, a wicked problem that requires a holistic approach. It is common knowledge that climate change, apart from civil unrest and wars that ravage the continent, is one of the contributory factors and drivers of rural poverty, which drives rural to urban migration. Therefore, addressing sustainability becomes a complex issue that requires the 
reconfiguration of governance systems to ensure urban transformation in line with the aspirations of SDG11 as espoused by Patel (2017).

Besides the City of Cape Town, other coastal urban areas have been threatened by floodings, such as George and Hermanus. There are also other important tourist resort towns where millions of rand worth of property have been damaged. The floods have been blamed for the destruction of tourism infrastructure, often located in pristine areas close to nature. Floods in the Western Cape have often cut off routes to some of the province's tourism destinations, such as Agulhas National Park, where the primary link road becomes flooded during intense rainfall as the road runs through a significant wetland area. Flooding, therefore, undermines economic activities in the province. Figure 6 shows the damage which occurred in May 2005 on the R43 highway, which links Hermanus to Stanford.

Looking at the global scale, addressing global warming that leads to climate change, and in turn, weather extreme events, in this case, the threat of flooding, will require both local and national governments to embrace climate change mitigation strategies. This, therefore, demands implementing measures aimed at reducing the carbon footprint of the province and all its metros. The province has an obligation to reduce its emissions under the Paris Agreement, and one way of doing this is an investment in clean energy such as wind and solar, which requires an investment in energy efficiency technologies. Investment in clean energy should address challenges of energy, climate change and unemployment in the province. One of the ways of decreasing disaster vulnerability in Africa is through the addressing of poverty and inequality.

SDG 16 Target 16.3 speaks about the need to ensure the rule of law. This is a critical issue with regards to developing a sustainable urban community within the province of the Western Cape. One of the challenges faced by urban areas in South Africa is non-adherence to city by-laws and national legislative provisions, with environmental laws often being flouted for political expediency. Strict adherence to environmental laws and enforcement of environmental laws can ensure that people do not settle in fragile and ecosensitive areas such as wetland, waterways and protected coastal zones and estuaries, which are often risky areas. Adherence and enforcement of environmental laws will ensure that some of the populations now located in risk and disaster areas are relocated to safe zones where proper urban planning has been taken into consideration to reduce flood risk.

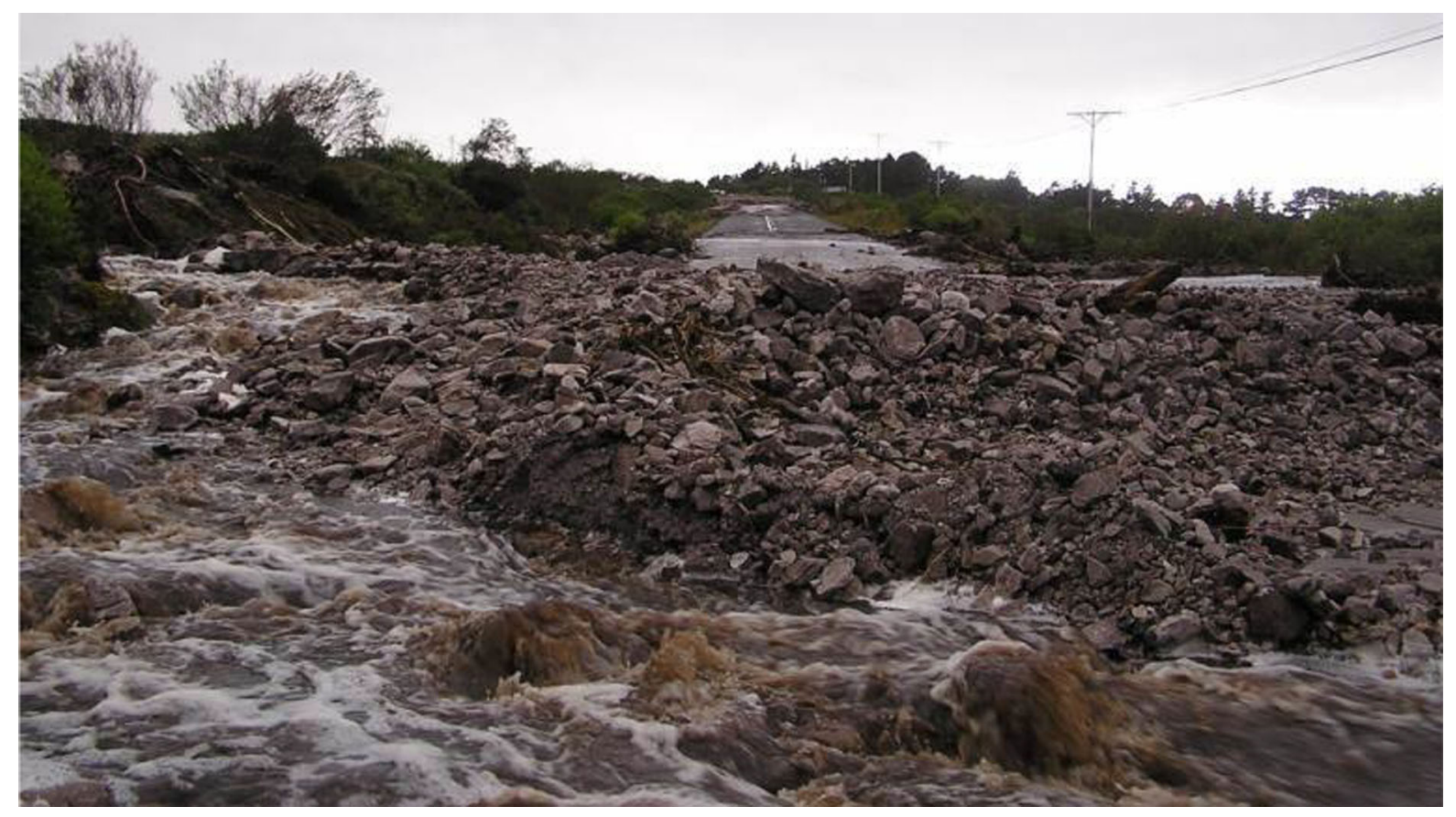

Fig. 6 Impacts of severe flooding in Hermanus on transport infrastructure. Source: Overstrand Municipality 
Colenbrander (2019) argues that despite the transition to democracy and adopting a white paper on sustainable development fairness and inclusivity, the paper is still elusive regarding reducing risk and vulnerability in coastal management in South Africa. SDG Targets 16.6 and Target 16.7 further speak about ensuring the need to develop effective and transparent, and accountable institutions at all levels. They also speak about the need to foster responsive, inclusive, participatory and representative decision making at all levels. The Western Cape government has often come under fire for directing a considerable share of its resources towards the wealthy elite at the expense of the marginalised (Black et al., 2020). This has entrenched and extended inequality in many respects, which has negated the poor to live in squaller conditions. In a bid to reduce risk, the provincial government might need to relook at resource allocation to provide the much needed essential services and deliver on promises of housing for all as a strategy of reducing the housing backlog. This should also provide affordable housing, which will take large segments of the population out of informal settlements. Given the scope and demand for safe housing, there might be a need for the national government, civil society, and private players to roll out housing for the poor and low, middle-income earners who are often at the receiving end of the flooding disasters that affect the province. While there is evidence (Fig. 7) that there has been an increase in people living in formal housing, there is a need to arrest the increasing number of people living in informal settlements, most of whom are at the mercy of extreme weather events such as flooding in the Western Cape. A reduction in housing backlog is one good starting point. The Western Cape's housing backlog is estimated at a staggering 600,000 as of the year 2020 , according to a report by Gontsana (2020).

One of the challenges that are likely to be faced in housing is the issue of land to relocate people located in climate disaster zones. Releasing state land for human settlement to construct affordable housing and rural development houses is a must in addressing the problem. This has to be done in a holistic manner that does not seek to score cheap political points, as we have seen during the Day Zero drought phenomenon (Nhamo \& Agyepong, 2019). One other problem from flooding has been the clogging of water systems with either overgrown vegetation or waste, or both. Work by Echendu (2020) in Nigeria, Abass et al. (2020) in Ghana, Mahmood et al. (2017) in Khartoum, and Dalu et al. (2018) in the Eastern Cape, South Africa, show that poor drainage and drainage clogging, compounds flooding in urban areas. The Western Cape is not unique, as in high density suburbs, the infrastructure maintenance and refuse collection is rather lax. The phenomenon has worsened the impacts of flooding in the city with calls for dredging of weeds overgrowth in waterways; improved refuse collection and waste management calls being made to ensure that there is a substantial reduction of risk of flooding.
Fig. 7 Western Cape Household by dwelling type 1995-2016. Source: Authors, Data from Stats SA

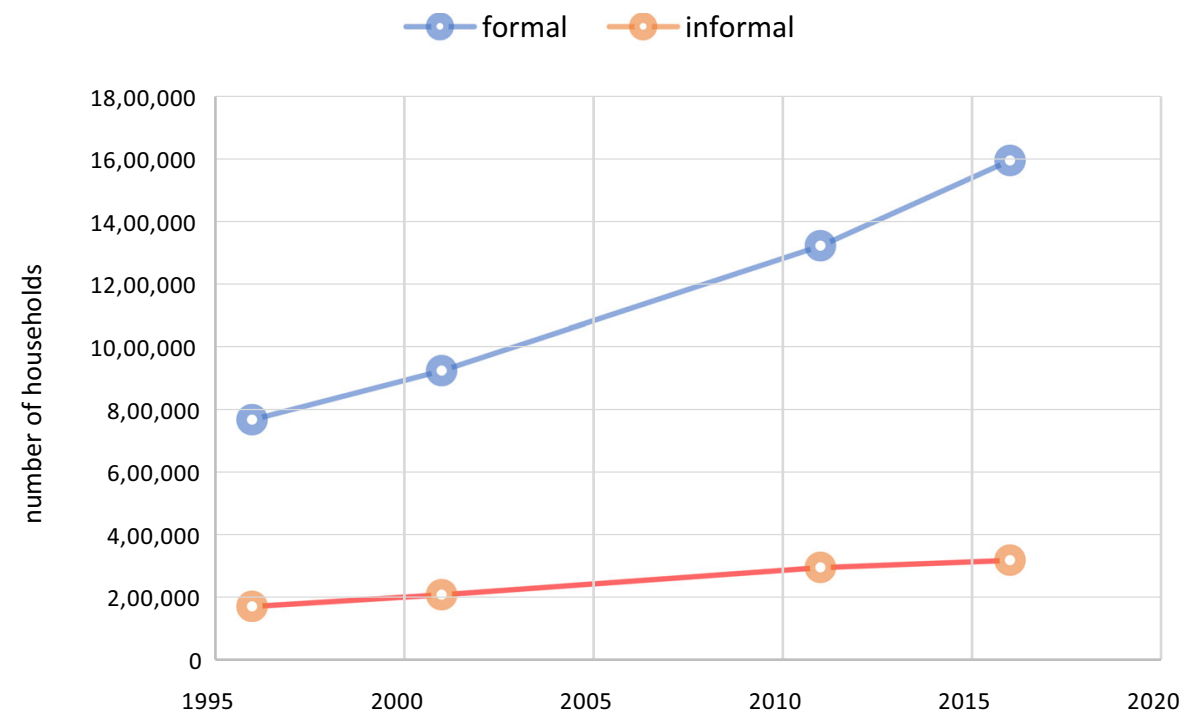




\section{Conclusions}

The study sought to investigate the trends and impacts of floods in the Western Cape Province of South Africa. Making use of the Mann-Kendall Trend test, the study established that there is a statistically significant increase in the number of flood events that are taking place in the Western Cape province. The study also found that some of the most vulnerable areas to flooding includes Knysna, George, Hermanus and cape flats in Cape Town, to mention but a few. Floods compounded with other urban challenges have led to an increase in the human and economic costs of floods, with some floods costing millions and, in some cases, billions of rand. The loss of property, infrastructure and human lives makes floods an urgent concern that requires urgent attention from development practitioners, city planners, government and ordinary residents to ensure sustainability. Given that flood risk is a result of multiple factors that interact to produce disaster situations for mainly urban areas, there is a need for concerted efforts to put in place measures that build community resilience to floods and build back better thereby producing climate smart societies. The study recommends an integrated approach to the management of flooding in the Western Cape province as part of ensuring urban sustainability. Addressing the flooding challenges further requires a holistic approach that takes into account climate change and other urban challenges such as land grabs, urban sprawling and associated challenges. Lastly, both the private and public sector players need to work together to build climate start infrastructure and insure critical infrastructure against flood hazards given their significant increase over time.

\section{Declarations}

Conflict of interest There is no conflict of interest in conducting and writing the article.

Compliance with ethical standards This serves to declare that myself Kaitano Dube on my behalf and on behalf of the coauthors Godwell Nhamo and David Chikodzi all from University of South Africa are the sole authors of the article Trends and impacts of floods in coastal communities of the Western Cape province in South Africa which we have submitted for publication consideration in GeoJournal. All the authors participated enough to be considered authors of the article. We further attest that all third-party material has been acknowledged. The research was conducted in line with ethical provisions as provided by researcher institutions.

\section{References}

Abass, K., Buor, D., Afriyie, K., Dumedah, G., Segbefi, A. Y., Guodaar, L., Garsonu, E. K., Adu-Gyamfi, S., Forkuor, D., Ofosu, A., \& Gyasi, R. M. (2020). Urban sprawl and green space depletion: Implications for flood incidence in Kumasi, Ghana. International Journal of Disaster Risk Reduction, 51(2), 433.

Adelekan, I. O. (2010). Vulnerability of poor urban coastal communities to flooding in Lagos Nigeria. Environment and Urbanization, 22(2), 433-450.

Amoako, C., \& Frimpong Boamah, E. (2015). The three-dimensional causes of flooding in Accra, Ghana. International Journal of Urban Sustainable Development, 7(1), 109-129.

Balica, S. F., Wright, N. G., \& Van der Meulen, F. (2012). A flood vulnerability index for coastal cities and its use in assessing climate change impacts. Natural Hazards, 64(1), 73-105.

Black, G. F., Liedeman, R., \& Ryklief, F. (2020). Using hand maps to understand how intersecting inequalities affect possibilities for community safety in Cape Town. Community Development Journal, 55(1), 26-44.

Braccio, S. (2014). Flood-prone areas due to heavy rains and sea level rise in the municipality of Maputo. Climate change vulnerability in Southern African cities (pp. 171-185). Cham: Springer. https://doi.org/10.1007/978-3-31900672-7_11.

Cian, F., Blasco, J., \& Carrera, L. (2018). Towards resilient flood risk management for Asian coastal cities: Lessons learned from Hong Kong and Singapore. Journal of Cleaner Production, 187(3), 576-589.

Cian, F., Blasco, J. M. D., \& Carrera, L. (2019). Sentinel-1 for monitoring land subsidence of coastal cities in Africa using PSInSAR: A methodology based on the integration of SNAP and staMPS. Geosciences, 9(3), 124.

Colenbrander, D. (2019). Dissonant discourses: Revealing South Africa's policy-to-praxis challenges in the governance of coastal risk and vulnerability. Journal of Environmental Planning and Management, 62(10), 1782-1801.

Dalu, M. T., Shackleton, C. M., \& Dalu, T. (2018). Influence of land cover, proximity to streams and household topographical location on flooding impact in informal settlements in the Eastern Cape, South Africa. International Journal of Disaster Risk Reduction, 28, 481-490. https:// doi.org/10.1016/j.ijdrr.2017.12.009.

Dhiman, R., VishnuRadhan, R., Eldho, T. I., \& Inamdar, A. (2019). Flood risk and adaptation in Indian coastal cities: Recent scenarios. Applied Water Science, 9(1), 5.

Dodman, D., Leck, H., Rusca, M., \& Colenbrander, S. (2017). African urbanisation and urbanism: Implications for risk accumulation and reduction. International Journal of Disaster Risk Reduction, 26, 7-15. https://doi.org/10.1016/ j.ijdrr.2017.06.029. 
Douglas, I. (2017). Flooding in African cities, scales of causes, teleconnections, risks, vulnerability and impacts. International Journal of Disaster Risk Reduction, 26(1), 34-42.

Douglas, I., Alam, K., Maghenda, M., Mcdonnell, Y., McLean, L., \& Campbell, J. (2008). Unjust waters: climate change, flooding and the urban poor in Africa. Environment and urbanization, 20(1), 187-205.

Dube, K., \& Nhamo, G. (2020a). Evidence and impact of climate change on South African national parks. Potential implications for tourism in the Kruger National park. Environmental Development, 33, 1-11. https://doi.org/10. 1016/j.envdev.2019.100485.

Dube, K., \& Nhamo, G. (2020b). Vulnerability of nature-based tourism to climate variability and change: Case of Kariba resort town, Zimbabwe. Journal of Outdoor Recreation and Tourism, 29, 100281. https://doi.org/10.1016/j.jort. 2020.100281.

Dube, K., Nhamo, G., \& Chikodzi, D. (2020). Climate changeinduced droughts and tourism: Impacts and responses of Western Cape province, South Africa. Journal of Outdoor Recreation and Tourism. https://doi.org/10.1016/j.jort. 2020.100319

Dube, K., Nhamo, G., \& Chikodzi, D. (2021). Rising sea level and its implications on coastal tourism development in Cape Town, South Africa. Journal of Outdoor Recreation and Tourism, 33, 100346. https://doi.org/10.1016/j.jort. 2020.100346.

Dube, K., Nhamo, G., \& Mearns, K. (2020). \&Beyond's Response to the twin challenges of pollution and climate change in the context of SDGs. In G. Nhamo, G. Odularu, \& V. Mjimba (Eds.), Scaling up SDGs implementation. Sustainable development goals series (pp. 87-98). Cham: Springer. https://doi.org/10.1007/978-3-030-33216-7_6.

Duy, P. N., Chapman, L., \& Tight, M. (2019). Resilient transport systems to reduce urban vulnerability to floods in emerging-coastal cities: A case study of Ho Chi Minh city Vietnam. Travel Behaviour and Society, 15, 28-43. https:// doi.org/10.1016/j.tbs.2018.11.001.

Echendu, A. J. (2020). The impact of flooding on Nigeria's sustainable development goals (SDGs). Ecosystem Health and Sustainability, 6(1), 1791735.

Enqvist, J. P., \& Ziervogel, G. (2019). Water governance and justice in Cape Town: An overview. Wiley Interdisciplinary Reviews: Water, 6(4), e1354.

Fitchett, J. M., Grant, B., \& Hoogendoorn, G. (2016). Climate change threats to two low-lying South African coastal towns: Risks and perceptions. South African Journal of Science, 112(5-6), 1-9.

Gontsana, M., 2020. Daily Maverick. [Online] Available at: Retrieved from 4 January 2021 https://www.dailymaverick. co.za/article/2020-03-26-housing-backlog-exceeds-half-amillion-in-western-cape/.

Gwaze, A., Hsu, T. T., Bosch, T., \& Luckett, S. (2018). The social media ecology of spatial inequality in Cape Town: Twitter and instagram. Global Media Journal-African Edition, 11(1), 1-20.

Hallegatte, S., Green, C., Nicholls, R. J., \& Corfee-Morlot, J. (2013). Future flood losses in major coastal cities. Nature Climate Change, 3(9), 802-806.
Hamed, K. H. (2008). Trend detection in hydrologic data: The Mann-Kendall trend test under the scaling hypothesis. Journal of Hydrology, 349(3-4), 350-363.

Handayani, W., Fisher, M. R., Rudiarto, I., Setyono, J. S., \& Foley, D. (2019). Operationalizing resilience: A content analysis of flood disaster planning in two coastal cities in Central Java, Indonesia. International Journal of Disaster Risk Reduction, 35, 101073. https://doi.org/10.1016/j.ijdrr. 2019.101073.

Hirabayashi, Y., Mahendran, R., Koirala, S., Konoshima, L., Yamazaki, D., Watanabe, S., Kim, H., \& Kanaen, S. (2013). Global flood risk under climate change. Nature Climate Change, 3(9), 816-821.

Hu, Z., Liu, S., Zhong, G., Lin, H., \& Zhou, Z. (2020). Modified Mann-Kendall trend test for hydrological time series under the scaling hypothesis and its application. Hydrological Sciences Journal, 45(14), 2419.

IPCC, 2019. Special report on the ocean and cryosphere in a changing climate, s.l.: IPCC.

Jiang, Y., Zevenbergen, C., \& Ma, Y. (2018). Urban pluvial flooding and stormwater management: A contemporary review of China's challenges and "sponge cities" strategy. Environmental Science \& Policy, 80, 132-143. https://doi. org/10.1016/j.envsci.2017.11.016.

Jordhus-Lier, D., Saaghus, A., Scott, D., \& Ziervogel, G. (2019). Adaptation to flooding, pathway to housing or 'wasteful expenditure'? Governance configurations and local policy subversion in a flood-prone informal settlement in Cape Town. Geoforum, 98, 55-65. https://doi.org/10.1016/j. geoforum.2018.09.029.

Kabanda, T. (2020). GIS modeling of flooding exposure in Dar es Salaam coastal areas. African Geographical Review, 39(2), 134-143.

Kim, Y., Eisenberg, D. A., Bondank, E. N., Chester, M. V., Giuseppe Mascaro, B., \& Underwood, S. (2017). Fail-safe and safe-to-fail adaptation: decision-making for urban flooding under climate change. Climatic Change, 145(3-4), 397-412.

Kithiia, J. (2011). Climate change risk responses in East African cities: Need, barriers and opportunities. Current Opinion in Environmental Sustainability, 3(3), 176-180.

Leal Filho, W., Balogun, A. L., Ayal, D. Y., Bethurem, E. M., Murambadoro, M., Mambo, J., \& Mugabe, P. (2018). Strengthening climate change adaptation capacity in Africa-case studies from six major African cities and policy implications. Environmental Science \& Policy, 86, 29-37. https://doi.org/10.1016/j.envsci.2018.05.004.

Leal Filho, W., Balogun, A. L., Olayide, O. E., Azeiteiro, U. M., Ayal, D. Y., Muñoz, P. D., \& Saroar, M. (2019). Assessing the impacts of climate change in cities and their adaptive capacity: Towards transformative approaches to climate change ada. Science of The Total Environment, 692, 1175-1190. https://doi.org/10.1016/j.scitotenv.2019.07. 227.

Liu, J., Xu, Z., Chen, F., Chen, F., \& Zhang, L. (2019). Flood hazard mapping and assessment on the Angkor world heritage site Cambodia. Remote Sensing, 11(1), 98.

Mahmood, M. I., Elagib, N. A., Horn, F., \& Saad, S. A. (2017). Lessons learned from Khartoum flash flood impacts: An integrated assessment. Science of the Total Environment, 
601, 1031-1045. https://doi.org/10.1016/j.scitotenv.2017. 05.260 .

Mirza, M. M. Q. (2003). Climate change and extreme weather events: Can developing countries adapt? Climate Policy, 3(3), 233-248.

Mukheibir, P., \& Ziervogel, G. (2007). Developing a municipal adaptation plan (MAP) for climate change: The city of Cape Town. Environment and Urbanization, 19(1), 143-158.

Nhamo, G., \& Agyepong, A. O. (2019). Climate change adaptation and local government: Institutional complexities surrounding Cape Town's day zero. Jàmbá: Journal of Disaster Risk Studies, 11(3), 1-9.

Nhamo, G., Dube, K., \& Chikodzi, D. (2020). Counting the Cost of COVID-19 on the global tourism industry (1st ed.). Switzerlerland: Springer International Publishing. https:// doi.org/10.1007/978-3-030-56231-1.

Ogie, R. I., Holderness, T., Dunn, S., \& Turpin, E. (2018). Assessing the vulnerability of hydrological infrastructure to flood damage in coastal cities of developing nations. Computers, Environment and Urban Systems, 68, 97-109. https://doi.org/10.1016/j.compenvurbsys.2017.11.004.

Park, S. J., \& Lee, D. K. (2020). Prediction of coastal flooding risk under climate change impacts in South Korea using machine learning algorithms. Environmental Research Letters, 15(9), 094052.

Patel, Z., Greyling, S., Simon, D., Arfvidsson, H., Moodley, N., Primo, N., \& Wright, C. (2017). Local responses to global sustainability agendas: learning from experimenting with the urban sustainable development goal in Cape Town. Sustainability science, 12(5), 785-797.

Phiri, D., Simwanda, M., \& Nyirenda, V. (2020). Mapping the impacts of cyclone Idai in Mozambique using Sentinel-2 and OBIA approach. South African Geographical Journal, 103(2), 237-258.

Rasmusson, E. M., \& Wallace, J. M. (1983). Meteorological aspects of the El Nino/southern oscillation. Science, 4629(222), 1195-1202.

Reimann, L., Vafeidis, A. T., Brown, S., Hinkel, J., \& Tol, R. S. J. (2018). Mediterranean UNESCO world heritage at risk from coastal flooding and erosion due to sea-level rise. Nature communications, 9(1), 1-11.
Ribot, J. (2014). Cause and response: Vulnerability and climate in the Anthropocene. The Journal of Peasant Studies, 41(5), 667-705.

Rouault, M., White, S. A., Reason, C. J. C., Lutjeharms, J. R. E., \& Jobard, I. (2002). Ocean-atmosphere interaction in the Agulhas current region and a South African extreme weather event. Weather and Forecasting, 17(4), 655-669.

South African Weather Service , 2019. Annual state of climate 2019, s.1.: South African Weather Service.

Stramma, L., \& Lutjeharms, J. (1997). The flow field of the subtropical gyre of the South Indian Ocean. Journal of Geophysical Research, 102(C3), 5513-5530.

Taylor, A. (2019). Managing stormwater and flood risk in a changing climate: Charting urban adaptation pathways in Cape Town. In D. Scott, H. Davies, \& M. New (Eds.), Mainstreaming climate change in urban development: Lessons from Cape Town (pp. 224-241). Cape Town: Cape Town University Press.

Taylor, A. \& Davies, H., 2019. An overview of climate change and urban development in cape town. Climate change and urban development: lessons from Cape Town. Cape Town: UCT Press.

United Nations, 2015. Agenda 2030 on sustainable development. [Online] Available at: Retrieved from 11 July 2020 https://sustainabledevelopment.un.org/content/documents/ $21252030 \% 20$ Agenda\%20for $\% 20$ Sustainable\% 20Development\%20web.pdf.

United Nations Office for Disaster Risk Reduction, 2015. Sendai Framework for Disaster Risk Reduction 2015-2030, s.1.: United Nations Office for Disaster Risk Reduction.

White, S. A., 2000. The influence of the Agulhas Current on two South African extreme weather events , Cape Town: (Doctoral dissertation, University of Cape Town)..

Zoleta-Nantes, D. B. (2002). Differential impacts of flood hazards among the street children, the urban poor and residents of wealthy neighborhoods in Metro Manila, Philippines. Mitigation and Adaptation Strategies for Global Change, 7(3), 239-266.

Publisher's Note Springer Nature remains neutral with regard to jurisdictional claims in published maps and institutional affiliations. 